\title{
DNA Methylation in Acacia mangium In vitro and Ex-vitro Buds, in relation to their Within-shoot Position, Age and Leaf Morphology of the Shoots
}

\author{
By O. Monteuuis ${ }^{\left.1),{ }^{*}\right)}$, F. C. Baurens ${ }^{1)}$, D. K. S. GoH ${ }^{2)}$, M. Quimado ${ }^{3)}$, S. Doulbeau ${ }^{4)}$ and J. L. Verdeil ${ }^{1)}$
}

(Received $13^{\text {th }}$ January 2009)

\begin{abstract}
DNA methylation was analyzed in Acacia mangium Willd. buds collected from in vitro and field growing shoots from the same clone and its juvenile offspring. Shoot tips from in vitro microshoots showed higher levels of DNA methylation for juvenile (23.4\%) than for mature $(21.8 \%)$ plant material, irrespective of their morphology. Likewise, under the same in vitro conditions, the apical buds collected from microshoots exhibiting the juvenile morphology displayed higher DNA methylation rates $(23.2 \%)$ than those characterized by the mature phyllode morphological type (22.1\%), regardless of the age of the plant material source. In outdoor conditions, apical buds collected from mature tree growing shoots were significantly less methylated (20.9\%) than the resting axillary buds located just underneath $(25.2 \%)$ and than the apical buds from the in vitro microshoots of the same clone and mature-like phyllode morphology (22.6\%). Overall, the DNA methylation levels found for our Acacia mangium plant materials were consistent with those reported for other Angiosperms, but showed, similarly to other recent findings in different species, that DNA methylation in plants does not always increase with ageing. This was discussed in relation to other phase-related traits and more particularly foliage characteristics, which are conspicuous markers of ageing in this heteroblastic species.
\end{abstract}

Key words: Acacia mangium, Ageing, DNA methylation, In vitro, Morphological markers, Within-shoot position.

\section{Introduction}

DNA methylation has been for a long time speculated to be associated with plant ageing (BoNGA, 1982), despite the lack of strong experimental data to support this idea (RAZIN and RIGGS, 1980). The prevailing hypothesis was that during the ontogenetical development of higher plants, genomic DNA could become more methylated, resulting in the modification or on and off switching of gene expression responsible for the varia-

1) CIRAD-BIOS, UMR 1098 DAP, TA A-96/03, avenue Agropolis, 34398, Montpellier, Cedex 5 France.

2) Yayasan Sabah Group, Biotechnology \& Horticulture Division, P.O. Box 11623, 88817 Kota Kinabalu, Sabah, Malaysia.

3) Department of Forest Biological Sciences, College of Forestry and Natural Reources, University of the Philippines Los Banos, Laguna 4031, Philippines.

4) IRD, UMR DIAPC, 911 Avenue Agropolis BP 6450, 34394 Montpellier Cedex 5 France.

*) Corresponding author: Olivier Monteuuis. CIRAD-BIOS, TA A-96/03, Avenue Agropolis, 34398, Montpellier, Cedex 5 France. Phone: 33 (0) 46761 7121, Fax: 33 (0) 467615605. E-Mail: olivier.monteuuis@cirad.fr tion of the maturational traits noticed (HoLLIDAY and PugH, 1975; RAzIN and RIGGS, 1980). Access to analytical methods for quantifying overall $5 \mathrm{mC}$ based on high performance liquid (HPLC) or even more sensitive capillary (HPCE) electrophoresis (FRAGA et al., 2002a) has given the opportunity to study this topic more extensively, especially on higher plants (FINNEGAN et al., 2000). Recent findings on Pinus radiata strengthen the view that DNA methylation, particularly in meristematic tissues, increases with ageing, to the extent that these authors have proposed to use the degree of methylation of genomic DNA as a physiological ageing marker in close relationship with the morphogenetic capacities of their experimental plant material (FRAGA et al., 2002c). However, so far, this conclusion is only supported by a very limited number of concrete results, particularly in trees. In larch, no significant difference of DNA methylation was observed between juvenile and mature scions (GREenwood et al., 1989) whereas, in Sequoiadendron giganteum, mature-like field growing clonal offspring derived from a 100-yr-old tree showed significantly lower DNA methylation rates than the rejuvenated line from the same original tree issued from meristem culture and maintained in vitro (MONTEUUIS et al., 2008). Tissue culture conditions seem to induce noticeable quantitative (hypermethylation) and qualitative changes in DNA methylation of the genome, which have been so far mainly investigated with regard to somaclonal variation, but more seldom related specifically to physiological ageing (LAMBÉ et al., 1997; VALLEDOR et al., 2007). However, for tissue cultured chestnut, HASBUN et al. (2005) found higher levels of methylated DNA in the juvenile-like microshoots than in the more mature-like ones originating from older parts of the same donor tree. In the heteroblastic tree species Acacia mangium Willd., DNA methylation degree was also higher in microshoots exhibiting a juvenile morphology than in their mature-like homologs from the same donor tree, regardless its age, while more qualitative agerelated DNA methylation markers could be detected by MSAP (BAURENS et al., 2004).

Ageing takes place in the apical meristems, as clearly demonstrated for a long time by leaf morphological changes in relation to the successive steps of ontogenetical development in heteroblastic species or in species with salient foliar dimorphism between juvenile and mature stages (SCHAFFALITZKY DE MUCKADELL, 1959). The intensity of the phenomenon varies according to the within-shoot position of the meristem, the apical meristems being ontogenetically older than the axillary ones (Fortanier and Jonkers, 1976; HacketT, 1985). There 
are several observations supporting the statement that tissue culture may influence physiological ageing, and even induce rejuvenation as reflected by various criteria including reversion from mature to juvenile morphological types (HACKETT, 1985; PIERIK, 1990; MONTEUUIS, 2004a).

The effect of these various factors on DNA methylation, not assessed yet, were analyzed on Acacia mangium, emphasizing the real advantage of choosing an heteroblastic species for studying the various aspects of ageing (SCHAFFALITZKY DE MUCKADELL, 1959; MONTEUUIS, 2004a).

\section{Materials and Methods}

\section{Plant material}

Apical buds collected from 2 to $3 \mathrm{~cm}$ long microshoots were used for the in vitro mature and juvenile sources of plant material. The mature source " 5 " was a clone ini-

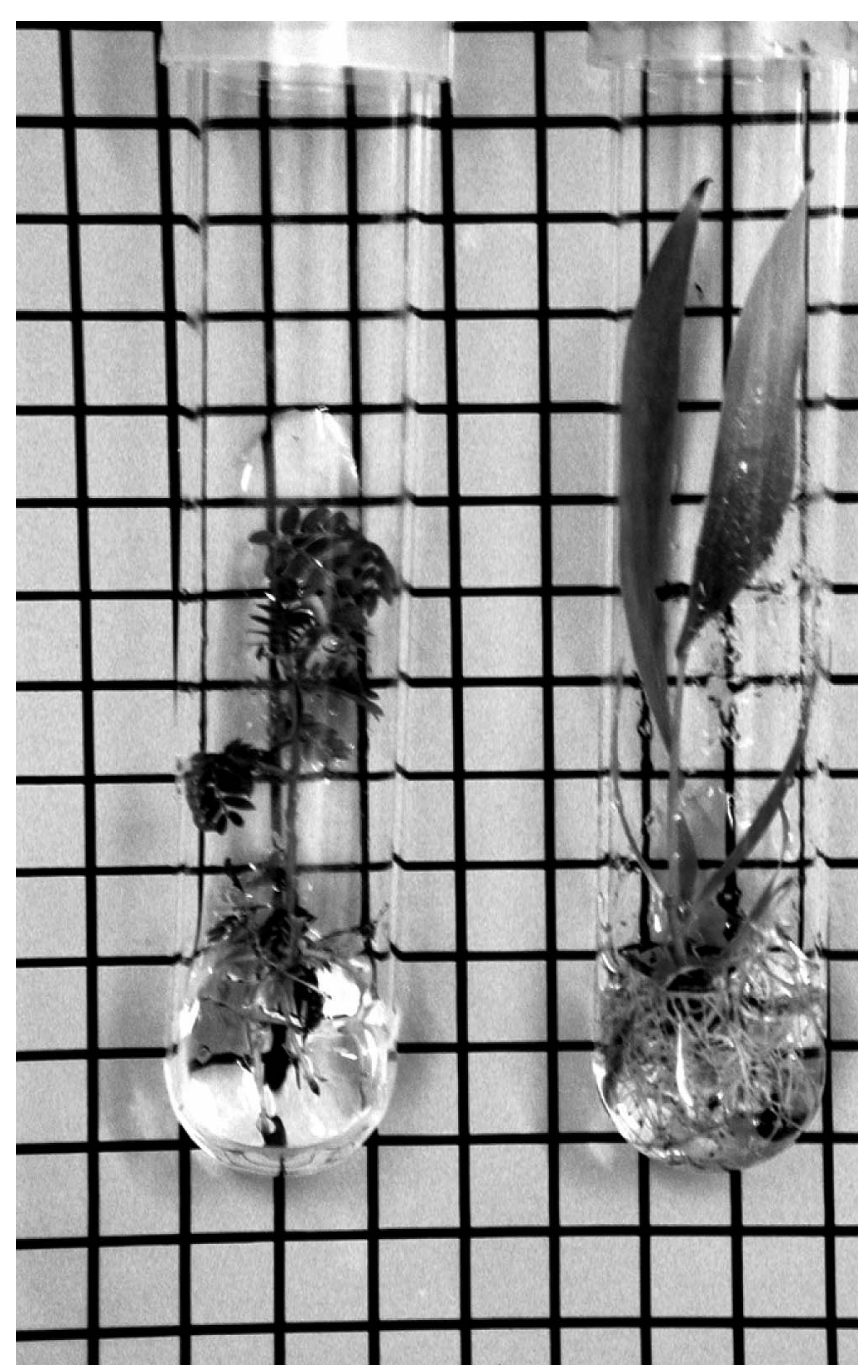

Figure 1. - Juvenile-like Acacia mangium microshoot characterized by compound leaves consisting of pinnates exclusively (on the left), whereas the mature-like type is characterized by phyllodes (on the right). The coexistence of these two contrasted morphological types could be observed within each age-class of plant material kept micropropagated in vitro. The black squares are $1 \mathrm{~cm}$ wide. tially obtained from 1 to $2 \mathrm{~cm}$ long nodal explants collected from the lower part of the crown of a 7-year-old mature Acacia mangium plus tree " 5 " growing outdoors in Sabah, East Malaysia. The juvenile source "P5" consisted of a mixture of seedlings germinated in vitro from the above mentioned " 5 " plus tree. These two sources of plant material had been kept for 6 years under micropropagation rigorously in the same conditions on a multiplication medium as specified in MonteuUIs (2004a and $b$ ), before collecting at the same time the samples for analyses. Microshoots from both sources grew in vitro developing juvenile morphology compound leaves with pinnates transforming gradually into the phyllode mature type, and vice versa alternately over time as stem elongated. Within each age class, the juvenile-like microshoots "J" bearing compound leaves only were separated from the mature-like ones " $\mathrm{M}$ " showing phyllodes exclusively (see Fig. 1). This gave rise to four classes of plant materials, "5J", "5M", "P5J", "P5M", resulting from the combination of the 2 different age classes (" 5 " and "P5") X the 2 different morphological types ("J" and "M"). These four classes were compared with regard to the degree of DNA methylation of their respective apical buds in the first experiment.

For the second experiment, apical buds and the closest axillary ones situated just underneath were collected from elongating shoots from the lower part -1 to $2 \mathrm{~m}$ above soil level - of a 4 yr-old and 19-20 m tall tree growing in Sabah, East Malaysia. This tree, bearing phyllodes exclusively and thus considered as physiologically mature (HACKETT, 1985), derived from clone 5 microshoots (MONTEUUIS et al., 2003). DNA methylation rates of these two origins of ex-vitro buds and of their in vitro apical homologs produced by the mature-like microshoots " $5 \mathrm{M}$ ", and collected at a different date than for the first experiment, were compared.

The "buds" used for the analyses consisted in fact of the bud per se - 1 to $2 \mathrm{~mm}$ as overall size - plus a short portion of shoot underneath, which corresponded to a total length of $5 \mathrm{~mm}$ for the whole bud sample.

Each category of plant material was immediately frozen after trimming in liquid nitrogen, then stored in a freezer at $-80^{\circ} \mathrm{C}$.

\section{Genomic DNA extraction}

Plant material DNA extraction was performed using a MATAB (Mixed Alkyl Trimethyl Amonium Bromide) procedure with the additional information: $250 \mathrm{mg}$ of plant sample were ground in liquid nitrogen then immediately incubated in $2 \mathrm{ml}$ of pre-warmed extraction buffer (100 mM Tris- $\mathrm{HCl} \mathrm{pH} 8,20 \mathrm{mM}$ ethylenediaminetetraacetic acid (EDTA), $1.4 \mathrm{M} \mathrm{NaCl}, 2 \% \mathrm{w} / \mathrm{v}$ MATAB, $1 \%$ w/v Poly Ethylene Glycol (PEG) 6000 and 0.5\%w/v Sodium sulfite, 20\% w/v Igepal CA630, 20\% w/v Lithium Dodecyl sulfate, $20 \% \mathrm{w} / \mathrm{v}$ Sodium deoxycholate) at $74^{\circ} \mathrm{C}$ for $20 \mathrm{~min}$. After purification with $2 \mathrm{ml}$ of CIAA (Chloroform/Isoamylalcohol 24:1, v:v), DNA extracts were precipitated with $1,6 \mathrm{ml}$ of isopropanol then resuspended in $1 \mathrm{ml}$ of buffer (50 mM Tris-HCl pH 8, $10 \mathrm{mM}$ EDTA, $0.7 \mathrm{M} \mathrm{NaCl}$ ) before purification on anion exchange columns QIAGEN TIP 20 following the manufacturer's instructions (QIAGEN, Valencia CA, USA). 


\section{HPLC analyses}

The method employed for DNA enzymatic hydrolysis was adapted from Jaligot et al. (2000). DNA samples (20 $\mathrm{g}$ g each) were added to 10 microliter of a $0.5 \mathrm{U} / \mu \mathrm{l}$ solution of nuclease P1 (Sigma N8630) and $35 \mu \mathrm{l}$ of a $0.017 \mathrm{U} / \mathrm{ul}$ solution of alkaline phosphatase (Sigma $\mathrm{P} 4252)$. The reaction volume was adjusted to $200 \mu \mathrm{l}$ with the digestion buffer $\left(30 \mathrm{mM} \mathrm{NaCH}_{3}, 0.1 \mathrm{mM} \mathrm{ZnCl}_{2}\right.$, $\mathrm{pH}$ 5.3). Hydrolysis of DNA to nucleosides was performed in triplicate at $37^{\circ} \mathrm{C}$ for $3 \mathrm{~h}$. The reaction was stopped by the addition of $490 \mu \mathrm{l}$ absolute ethanol; then the samples were centrifuged at $11,000 \mathrm{~g}$ for $15 \mathrm{~min}$. The supernatant was transferred to a new tube, vacuum-dried and nucleosides were resuspended in $1 \mathrm{ml}$ of sterile water. The extracts were then filtered $(0.2 \mu \mathrm{m})$ prior to HPLC analysis. An isocratic elution method was followed using a modified version of the buffer described by GEHRKE et al. (1984): $50 \mathrm{mM} \mathrm{KH}_{2} \mathrm{PO}_{4}, 8 \%$ [v/V] methanol, $\mathrm{pH} 3.5$ (instead of 4.4), on a Supelcosil LC$18 \mathrm{~S}$ reverse-phase column (SUPELCO Inc., Bellefonte, Pa., $25 \mathrm{~cm} \times 4.6 \mathrm{~mm}$; particles diameter: $5 \mu \mathrm{m}$ ), with a flow rate of $0.8 \mathrm{ml} / \mathrm{min}$ and a run time of $30 \mathrm{~min}$. The improved conditions used allowed highly efficient separation of the peaks corresponding to deoxycytidine (C) and uracil (compounds identified by their respective retention time and UV spectra). The effluent was monitored at the wavelength of $285 \mathrm{~nm}$ with a photodiode array detector (Beckmann Germany). The percentage of $5 \mathrm{mC}$ was calculated using the formula: $5 \mathrm{mC} /(\mathrm{C}+5 \mathrm{mC})$ where $5 \mathrm{mC}$ and $\mathrm{C}$ correspond to the automatically integrated surface areas of the respective chromatograph peaks.

\section{Statistical analyses}

Sixteen to eighteen and ten to thirteen independent analytical HPLC measurements, corresponding to eight and five different extracts, were performed for each origin of the first and second experiments, respectively. The data were statistically treated using first an analysis of variance computer program (GLM procedures, SAS Institute, Inc. 2000), then the Student-Newman Keuls mean comparison test (SOKAL and ROHLF, 1995) when the effect of the factor tested was found statistically significant. A probability level of $\mathrm{P} \leq 0.05$ was considered significant for all the statistical analyses. Results are expressed as means.

\section{Results and Discussion}

DNA methylation was found to be significantly influenced $(\mathrm{P}<0.0001)$ by the four categories of in vitro plant material assessed in the first experiment (Fig. 2), with the higher rates for the seedling-issued plant material exhibiting the juvenile morphology "P5J", and the lowest scores for the mature origin " $5 \mathrm{M}$ " bearing phyllodes exclusively. These results demonstrate once again (BAURENS et al., 2004; MoNTEUUIS, 2004a and b) that in tissue culture conditions, a mature Acacia mangium genotype can rejuvenate, at least to some extent, by recovering certain juvenile characteristics like the production of composed leaves associated to a higher proportion of methylated DNA cytosine, similarly to what was observed for the juvenile plant material. The fact that the analogy between of "P5J" and " $5 \mathrm{~J}$ " methylation rates was even stronger in a previous experiment (BAURENS et al., 2004) could be due to the possibility for phase-relat-

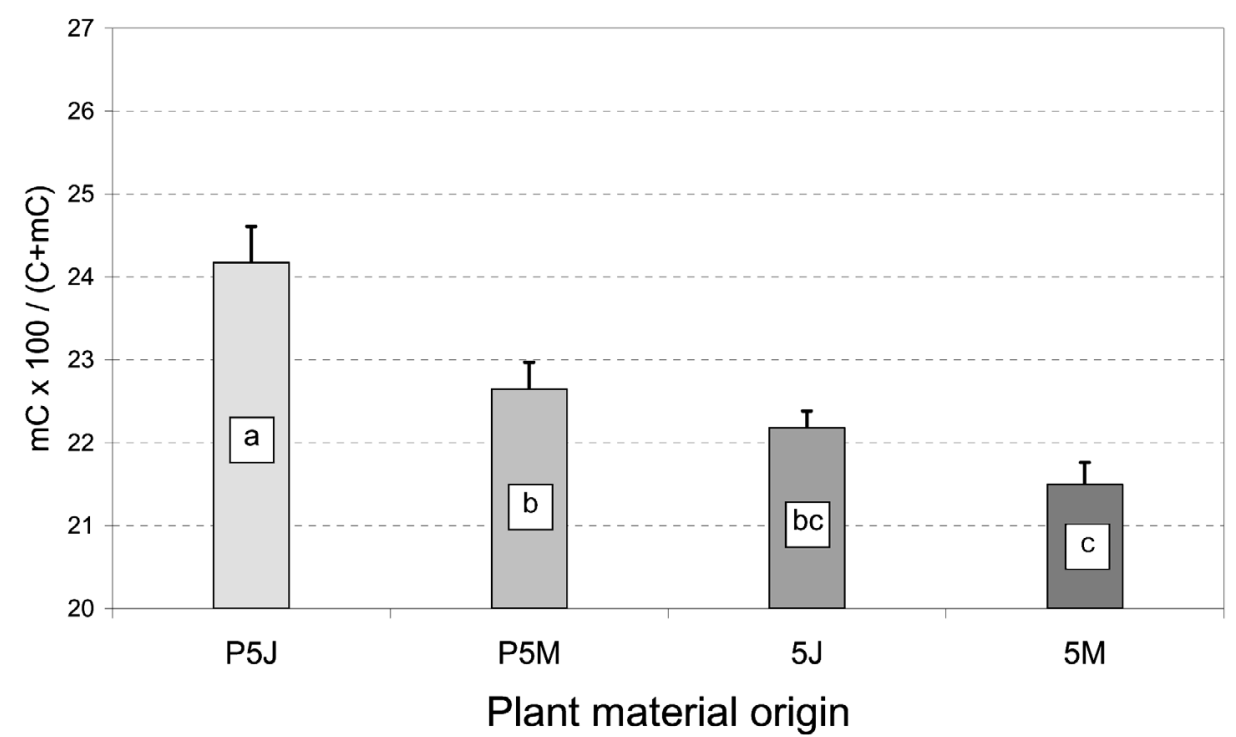

Figure 2. - Percentage of DNA methylation in the four categories of apical buds investigated in the first experiment i.e. the juvenile-like $(\mathrm{J})$ and mature-like $(\mathrm{M})$ microshoots of juvenile (P5) and mature (5) sources. Bars represent standard errors based on 16 to 18 measurements analyzed for each plant material category and different letters distinguish average values which are significantly different at the 5\% level (Student-Newman Keuls mean comparison test). 


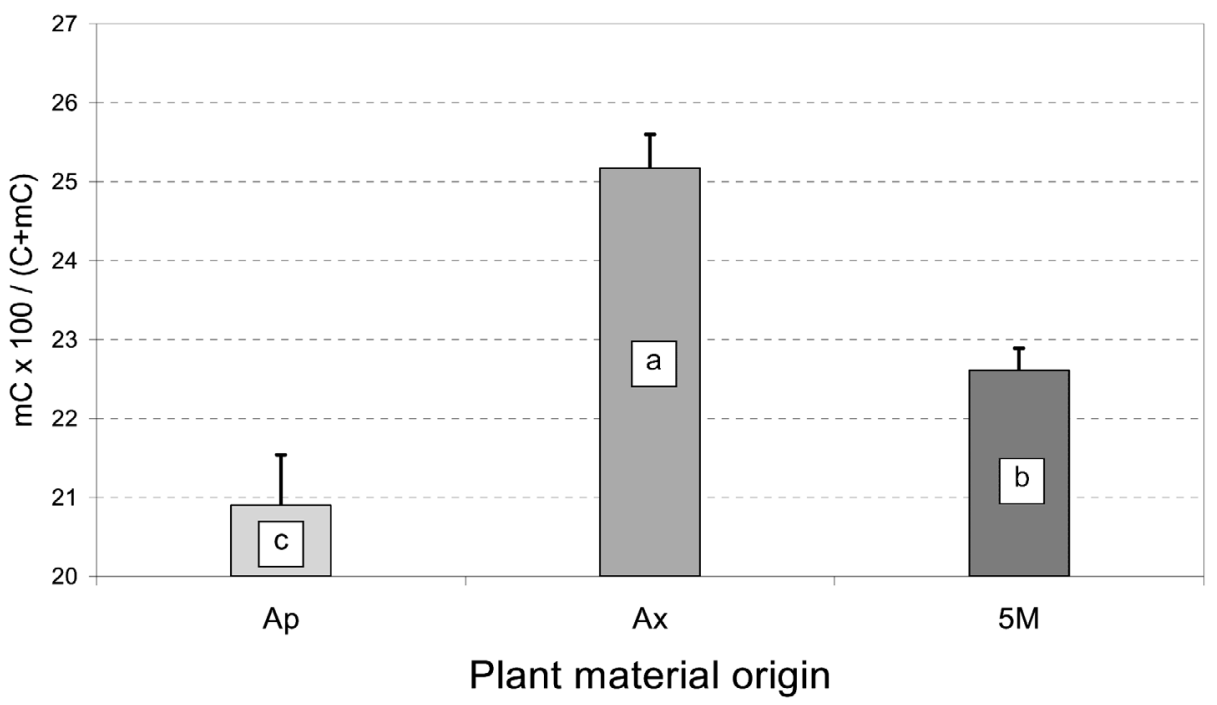

Figure 3. - Percentage of DNA methylation in the three categories of buds from the same mature clone 5 investigated in the second experiment i.e. apical (Ap) and axillary ( $\mathrm{Ax}$ ) buds collected from field elongating shoots, and apical buds from in vitro microshoots exhibiting the same mature-like phyllode morphology (5M). Bars represent standard errors based on 10 to 13 measurements analyzed for each plant material category and different letters distinguish average values which are significantly different at the $5 \%$ level (Student-Newman Keuls mean comparison test).

ed traits to vary not necessarily with the same intensity at the same time (BoRChert, 1976; PoETHIG, 1990; LAWson and PoETHig, 1995), as already observed for organogenic criteria on the same plant material and in the same experimental conditions (MonteuUIS, 2004b). Statistical analyses confirmed for the current study a marked influence $(\mathrm{P}<0.0001)$ of the age of the plant material, irrespective of its morphology, on the degree of DNA methylation, higher for the younger source than for the mature clone $(23.4 \%$ vs $21.8 \%$ as respective average values combining data for juvenile and mature leaf morphology for each age source). This finding is consistent with other observations on different species (GreEnwood et al., 1989; HASBún et al., 2005; MonteUUIS et al., 2008). Buds from microshoots exhibiting a juvenile morphology, irrespective of their age, had a noticeably higher proportion of methylated DNA cytosine than their homologs from the mature phyllode-type, with respective average values of $23.2 \%$ vs $22.1 \%$ $(\mathrm{P}<0.0011)$ when combining the two age classes. This is consistent with the conclusions of previous experiments on the same material (BAURENS et al., 2004), which did not point out also any age-related significant effect of shoot morphology on DNA methylation.

The three different origins of plant materials analyzed in the second experiment showed a marked DNA methylation rate contrast $(\mathrm{P}<0.0001)$, as illustrated in Fig. 3. Apical buds from outdoor elongating shoots appeared to be far less methylated (20.9\%) than the axillary buds located just underneath $(25.2 \%)$, thus ontogenetically slightly younger (ForTANIER and JoNkERs, 1976). This suggests again (GREENWOOD et al., 1989) that ageing, at least from an ontogenetical standpoint, may not be always associated with higher DNA methylation rates, contrary to what has been speculated for many years
(BonGA, 1982). Another aspect to take into consideration is that the apical buds were physiologically active, contrary to the axillary ones which became resting from the time they were formed by the organogenic apical meristem, and resting shoots were reported to be higher methylated than elongating ones (HASBUN et al., 2005; VALLEDOR et al., 2007). This could explain the difference in methylation degree found between these outdoor resting axillary buds and the actively growing apical ones produced by the in vitro microshoots of the same clone and phyllode morphology, also less methylated (22.6\% vs $25.2 \%)$. However, several morphological and organogenic indicators, such as adventitious rooting ability (MonTEuUIS, 2004a and b), suggest that these in vitro shoot tips might be physiologically younger (BorcherT, 1976; BoNGA, 1982; HACKETT, 1985) than their outdoor homologs, which could account for the higher levels of DNA methylation observed for the formers. This should not rule out the influence of possible in vitro culture-induced effects on DNA methylation of tissue cultured plant materials not necessarily associated with ageing (LAMBÉ et al., 1997; HASBUN et al., 2005; VALLEDOR et al., 2007). There is obviously a need to pursue such comparative in vitro versus ex vitro ageingrelated DNA methylation analyses and in this respect, the possibility to use plant material of the same clone to prevent genotypic interferences constitutes a real advantage.

The DNA methylation rates for the various types of plant materials investigated in our study ranged from $20.9 \%$ for the apical buds collected from field elongating shoots to $24.2 \%$ for the "P5 J" in vitro samples. The slight differences between the two experiments noticed for the same category of plant material, " $5 \mathrm{M}$ " samples for instance collected at two different dates, could be due 
to unpredictable variations of physiological state in the course of time already argued with regard to capacity for in vitro organogenesis of the same plant material (MonteuUIS, $2004 \mathrm{a}$ and b). Increment of DNA methylation rates according to the time spent in tissue culture conditions were also reported for various species (VALLEDOR et al., 2007). The experimental values obtained in this study are consistent with the levels of DNA methylation reported in the literature for many plants, mostly Angiosperms but also Gymnosperms (MonTEUUIs et al., 2008), utilizing the same HPLC methodology (DIAZ-SALA et al., 1995; Finnegan, 1996; FraGa et al., 2002a). The much higher $5 \mathrm{mC}$ methylation rates reported by FRAGA et al. (2002b) in Pinus radiata could be due to the nature of tissues used for the analyses (FrAGA et al., $2002 \mathrm{a}$ and b), with the possibility thanks to the bigger size of Pinus radiata meristems and to the higher sensitiveness of HPEC than HPLC technology (FRAGA et al., 2002 a), to restrict the investigations to the meristematic tissues only. This was not possible for Acacia mangium, like for a lot of species due to the much smaller size of the meristems - 30 to $40 \mu \mathrm{m}$ as overall height - and the bigger quantity of tissue samples required by the HPLC. The much bigger amount of differentiated versus meristematic tissues which constituted the bud samples analyzed in our study may explain the differences in DNA methylation observed with FRAGA et al. (2002). The particularities of HPEC protocols could also account for the higher DNA methylation values relevantly obtained than usually reported for HPLC (FRAGA and Esteller, 2002; FraGA et al., 2002a; VALLEDOR et al., 2007).

\section{References}

Baurens, F. C, J. Nicolleau, T. Legavre, J. L. Verdeil and O. MONTEUUIS (2004): Genomic DNA methylation of juvenile and mature Acacia mangium micropropagated in vitro with reference to leaf morphology as a phase change marker. Tree Physiology 24: 401-407.

BonGA, J. M. (1982): Vegetative propagation in relation to juvenility, maturity and rejuvenation. In: BonGA, J. M., Durzan, D. J. (eds). Tissue culture in forestry. Martinus Nijhoff/Dr. W. Junk publishers, The Hague, pp 387-412.

BoRCHERT, R. (1976): The concept of juvenility in woody plants. Acta Horticulturae. 56: 57-69.

Diaz-Sala, C, M. Rey, A. Boronat, R. Besford and R. RODRIGUEZ (1995): Variations in the DNA methylation and polypeptide patterns of adult hazel (Corylus avellana L.) associated with sequential in vitro subcultures. Plant Cell Reports 15: 218-221.

Finnegan, E. J. (1996): The Role of DNA methylation in plant development. In: Russo, V. E. A., Martienssen, R. A., RigGs, A. D. (eds). Epigenetic mechanisms of gene regulation. E Cold Spring Harbor Laboratory Press, New York, pp 127-140.

Finnegan, E. J., W. J. Peacock and E. S. Dennis (2000): DNA methylation, a key regulator of plant develomment and other processes. Current Opinion in Genetics and Development 10: 217-223.

Fortanier, E. J. and H. Jonkers (1976): Juvenility and maturity of plants as influenced by their ontogenetical and physiological ageing. Acta Horticulturae 56: 37-43.
FrAGA, M. F. and M. EsTELLER (2002): DNA methylation: a profile of methods and applications. Biotechniques, 33: 632-649.

Fraga, M. F., E. Uriol, L. B. Diego, M. Berdasco, M. Esteller, M. J. CANal and R. Rodriguez (2002a): High-performance capillary electrophoretic method for the quantification of 5-methyl 2'-deoxycytidine in genomic DNA: application to plant, animal and human cancer tissues. Electrophoresis 23: 1677-1681.

Fraga, M. F., R. Rodriguez and M. J. CANAL (2002b): Genomic DNA methylation-demethylation during aging and reinvigoration of Pinus radiata. Tree Physiol. 22: $813-816$.

Fraga, M. F., M. J. CANAL and R. Rodriguez (2002c): In vitro morphogenic potential of differently aged Pinus radiata trees correlates with polyamines and DNA methylation levels. Plant Cell Tissue and Organ Culture 70: 139-145.

Gehrke, C. W., R. A. McCune, M. Gama-Sosa, M. Enrlich and K. C. KUO (1984): Quantitative reverse-phase highperformance liquid chromatography of major or modified nucleosides in DNA. J. Chromatogr. 301: 199-219.

Greenwood, M. S., C. A. Hopper and K. W. Hutchinson (1989): Maturation in larch. I. Effect of age on shoot growth, foliar characteristics, and DNA methylation. Plant Physiology. 90: 406-412.

HACKETT, W. P. (1985): Juvenility, maturation, and rejuvenation in woody plants. Horticultural Reviews, 7: 109-155.

Hasbún, R., L. Valledor, M. Berdasco, E. Santamaria, M. J. CAÑAL, R. Rodriguez, D. Rios and M. SÁnchez (2005): In vitro proliferation and genome DNA methylation in adult chestnuts. Acta Horticulturae. (Ishs) 693: 333-340.

Holliday, R. and J. E. PUGH (1975): DNA modification mechanisms and gene activity during development. Science 187: 226-232.

Jaligot, E., A. Rival, T. Beulet, S. Dussert and J. L. VERDEIL (2000): Somaclonal variation in oil alm (Elaeis guineensis Jacq.): the DNA methylation hypothesis. Plant Cell Reports. 7: 684-690.

Lambé, P., H. S. N. Mutambel, J. G. Fouché, R. Deltour, J. M. FOIDART and T. GASPAR (1997): DNA methylation as a key process in regulation of organogenic totipotency and plant neoplastic progression? In Vitro Cell Dev. Biol.-Plant 33: 155-162.

Lawson, E. J. R. and R. S. Poethig (1995): Shoot development in plants: time for a change. Trends in Genetics, 11(7): 263-267.

MonteuUis, O. (2004a): In vitro rooting of juvenile and mature Acacia mangium microcuttings with reference to leaf morphology as a phase change marker. Trees $\mathbf{1 8}$ (1): 77-82.

MoNTEUUIS, O. (2004b): In vitro micropropagation and rooting of Acacia mangium microshoots from juvenile and mature origins In Vitro Cellular and Developmental Biololgy-Plant, 40: 102-107.

Monteuuis, O., D. Alloysius, C. Garcia, D. GoH and R. BACILIERI (2003): Field behavior of an in vitro-issued Acacia mangium mature selected clone compared to its seed-derived progeny. Australian Forestry, 66 (2): 87-89.

Monteuuis, O., S. Doulbeau and J. L. Verdeil (2008): DNA methylation in different origin clonal offspring from a mature Sequoiadendron giganteum genotype. Trees 22: 779-784. 
PIERIK, R. L. M. (1990): Rejuvenation and micropropagation. In: NikKamp, H. J. J., VAN DeR Plas, L. H. W., VAN AARTRIJK, J. (eds). Progress in Plant Cellular and Molecular Biology. Proceeds of the VII ${ }^{\text {th }}$ Inter. Congress on Plant Tissue and Cell Culture, Amsterdam, Netherland, pp 91-101.

POETHIG, R. S. (1990): Phase change and the regulation of shoot morphogenesis in plants. Science 250: 923-930.

RAZIN, A. and A. D. RIGGS (1980): DNA methylation and gene function. Science, 210: 604-610.

SAS Institute, Inc. (2000): SAS/STAT User's Guide, Cary, NC, USA.
SCHAFFALITZKY DE MUCKADELL, M. (1959): Investigations on aging of apical meristems in woody plants and its importance in silviculture. Kandrup and Wunsch's Bogtrykkeri, København, pp 313-346.

SokAL, R. R. and F. J. RoHLF (1995): Biometry. WH Freeman and Company, New York, USA, 887p.

Valledor, L., R. Hasbún, M. Meijon, J. L. Rodriguez, E. Santamaria, M. Viejo, M. Berdasco, I. Feito, M. F. Fraga, M. J. CANAL and R. Rodriguez (2007): Involvement of DNA methylation in tree development and micropropagation. Plant Cell Tissue and Organ Culture 91: 75-86.

\title{
Efficiencies of Clonally Replicated and Seedling Testing for Spruce Breeding and Deployment Strategies
}

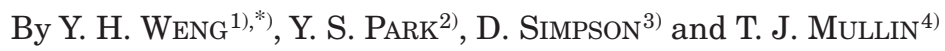 \\ (Received $18^{\text {th }}$ February 2009)
}

\begin{abstract}
Genetic gains based on a genetic test using clonal replicates were compared to those based on a test using seedlings at the same gene diversity and testing effort levels using POPSIM ${ }^{\mathrm{TM}}$ Simulator. Three testing and deployment strategies targeting for white spruce (P. glauca [Moench] Voss) and black spruce (P. mariana (Mill.) B.S.P.) in New Brunswick were compared: seedling test with clonal seed orchard deployed as seedlings (CSO_ST), clonally replicated test with clonal seed orchard deployed as seedlings (CSO_CRT), and clonally replicated test deployed as a clone mix (MVF). The breeding populations (BP) were formed by balanced within-family selection and the production populations (PP) were selected by strong restriction on relatedness, i.e., no parent in common. Compared to the seedling
\end{abstract}

1) New Brunswick Department of Natural Resources, Kingsclear Forest Nursery, Island View, NB, Canada, E3E $1 \mathrm{G} 3$.

2) Natural Resources Canada, Canadian Forest Service-Canadian Wood Fibre Centre, P.O. Box 4000, Fredericton, NB, Canada, E3B 5P7.

3) Natural Resources Canada, Canadian Forest Service-Atlantic Forestry Centre, P.O. Box 4000, Fredericton, NB, Canada, E3B 5 P7.

$\left.{ }^{4}\right)$ BioSylve Forest Science NZ Limited, 45 Korokoro Road, Lower Hutt 5012, New Zealand.

*) Corresponding author: Telephone 506-444-5125, Fax 506-4444917. E-Mail: $\underline{\text { Yuhui.Weng@ggnb.ca }}$ test, the clonally replicated test resulted in faster accumulation of additive effects but quicker loss of additive variance in the $\mathrm{BP}$, and this is particular true in the case of lower narrow-sense heritability or less non-additive genetic variance. The quicker loss in $\mathrm{BP}$ additive variance was overcompensated for by its faster accumulation in $\mathrm{BP}$ additive effect, resulting in higher gain in the clonally replicated test based PPs. Compared to the CSO_ST, the gain superiority of the CSO_CRT increased with generations, decreasing narrow-sense heritability or reducing the amount of non-additive variance. Implementing MVF was the most effective in terms of gain in most simulated cases and its superiority over the CSO_ST increased with generations, decreasing narrowsense heritability, or increasing non-additive genetic variance. Overall results demonstrated significant advantages of using clonally replicated test both for BP advancement and PP selection in most of the scenarios, suggesting that clonally replicated test should be incorporated into current spruce breeding strategies.

Key words: breeding population, production population, multivarietal forestry, clonal seed orchard, genetic gain, status number.

\section{Introduction}

Most tree breeding strategies have adopted a recurrent selection scheme to generate successive generations of a breeding population (BP). Superior phenotypes are selected to form a BP and are inter-mated and their 